\title{
Modified guarded hot plate apparatus for measuring thermal conductivity of moist materials
}

\author{
Madsen, Th. Lund
}

Publication date:

1969

Document Version

Publisher's PDF, also known as Version of record

Link back to DTU Orbit

\section{Citation (APA):}

Madsen, T. L. (1969). Modified guarded hot plate apparatus for measuring thermal conductivity of moist materials. Technical University of Denmark, Department of Civil Engineering.

\section{General rights}

Copyright and moral rights for the publications made accessible in the public portal are retained by the authors and/or other copyright owners and it is a condition of accessing publications that users recognise and abide by the legal requirements associated with these rights.

- Users may download and print one copy of any publication from the public portal for the purpose of private study or research.

- You may not further distribute the material or use it for any profit-making activity or commercial gain

- You may freely distribute the URL identifying the publication in the public portal

If you believe that this document breaches copyright please contact us providing details, and we will remove access to the work immediately and investigate your claim. 
INSTITUT INTERNATIONAL DU FROID

INTERNATIONAL INSTITUTE OF REFRIGERATION

\author{
LABORATORIET FOR VARMEISOLERING \\ DANMATKS TEKNICKE HØJSKOLE \\ IMEDELELSENR. 19.
}

\title{
MODIFIED GUARDED HOT PLATE APPARATUS \\ FOR MEASURING THERMAL CONDUCTIVITY OF MOIST MATERIALS
}

Th. LUND MADSEN

The Thermal Insulation Laboratory, The Technical University Lyngby (Denmark)

\author{
LABORATORIET FOR \\ VARMEISOLERING \\ DANMARKS TEKNISKE HOJSKOLE \\ BYGNING 118, 2800 LYNGBY \\ $1364^{\text {TELEFON (01) } 883511} \mathrm{M-1}$
}

Commissions II \& VI, Liège 1969, Annexe 1969-7

Supplément au Bulletin de l'Institut International du Froid - Extrait 


\title{
MODIFIED GUARDED HOT PLATE APPARATUS \\ FOR MEASURING THERMAL CONDUCTIVITY \\ OF MOIST MATERIALS
}

\author{
Th. LUND MADSEN \\ The Thermal Insulation Laboratory, The Technical Unicersity \\ Lingby (Denmark)
}

\begin{abstract}
Méthode modifiée de la plaque chaude gardée pour la détermination de la conductivité thermique des matériaux humides

RÉSUMÉ : La plupart des matériaux de construction conticnnent un certain pourcentage d'eau, ce qui a pour résultat une conducticité thermique élevée par rapport à celle du matériau sec. On estime que les meilleures méthodes de détermination de la conducticité thermique de matériaux humides sont généralement les méthodes rapides utilisant l'établissement d'un flux de chaleur non permanent. Tontefois une méthode qui permettrait de mesurer la conductivité thermique sous des flux simultanés de chaleur et d'humidité serait plus en rapport avec les conditions pratiques.

L'article décrit un dispositif modifié de la plaque chaude gardée où l'échantillon est séparé de la plaque chaude et de la plaque froide par des lames d'air dans lesquelles circule un air conditionné bien défini. Après l'établissement de régimes stationnaires de températures et d'humidité, le flux de chaleur et l'écart de température à travers l'échantillon sont mesurés et la conductivité est calculée à partir de ces caleurs.
\end{abstract}

\section{INTRODUCTION}

It is generally known that the determination of thermal conductivity presents problems because the change in temperature gradient, which the test involves, creates an unwanted vapor movement in the material. By measuring with an ordinary guarded hot-plate apparatus the vapor will move towards the cold surface, from where it has no possibility of escaping, as it normally can do in correctly made, practical constructions.

To get round this problem, a series of non-stationary methods has, in the course of time, been developed (O. Krischer and H. Esdorn, van der Held, Vos and others). The common factor in all these methods is that attempts are made to determine thermal conductivity before the vapor has managed to move appreciably. This does not correspond particularly well to practical circumstances where one usually has both a heat and a vapour transport through the building material from the hot to the cold side.

In an attempt to simulate the practical situation during laboratory experiments better than till now, the laboratory has constructed a modified guarded hot-plate apparatus where it is possible to impress a constant vapor gradient simultaneously on a specimen.

\section{MOdIFIED GUARDED HOT-PLATE APPARATUS}

In principle, the apparatus is built like a classical double-sided guarded hot-plate apparatus. It is intended for specimen with a total area of $30 \times 30 \mathrm{~cm}$ of which the actual measuring area amounts to $20 \times 20 \mathrm{~cm}$.

The construction of the guarded hot-plate apparatus is shown in figure 1. The heating element itself is made of $3 \mathrm{~mm}$ pertinax sheet, which is evenly winded with $1.5 \times 0.1 \mathrm{~mm}$ kanthalband. On both sides of the heating element, and electrically 


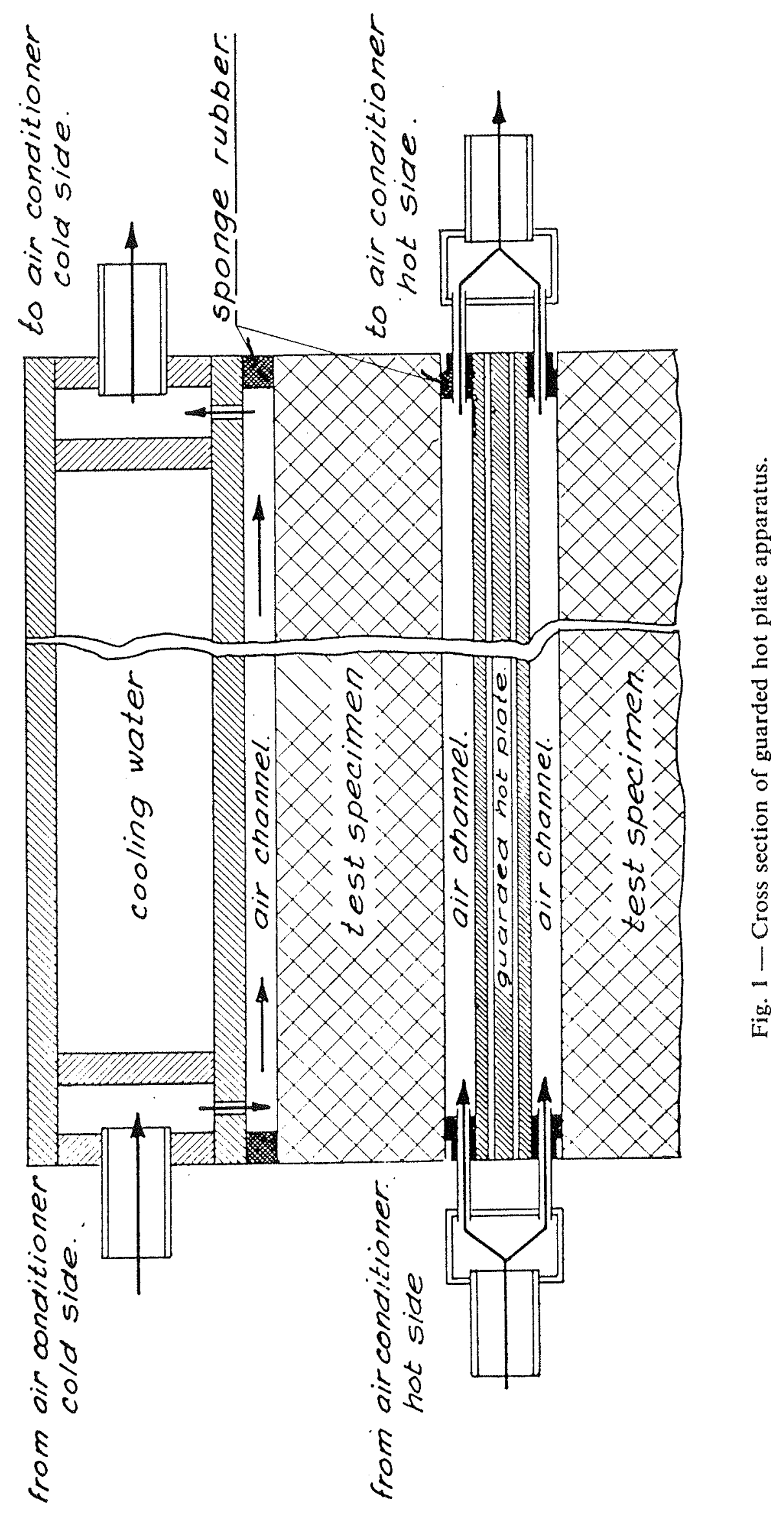


isolated from it, is a $2 \mathrm{~mm}$ thick aluminium sheet with a $2 \mathrm{~mm}$ gap which thermally divides the metering panel and the border panel. Thermal elements are moulded in the grooves in the aluminium sheets so that it is possible to determine the difference in temperature between the metering panel and the border panel with an accuracy of $\pm 0.01 \mathrm{deg} C$.

The cooling plates are constructed as flat aluminium boxes through which cooled water flows, like through a labyrinth. The temperature of the cooled water is regulated by help of a unit whose principle is shown in figure 2 .

A volume of water of 90 litres circulates between the two cooling plates. These are fixed in series with a pump so as to yield about 100 litres per minute. After the passage through the cooling plates, the water is guided through a heat exchange where the water's temperature is reduced about $1 / 10 \mathrm{deg} C$, because the cooling effect is constant and about 500 Watt.

Regulation of the temperature is made with an electric heating element, which is governed with the help of a transistorised contact thermometer. The thermometer is placed in such a way that water passes it directly after it passes the heating element. This causes a quick regulation frequency, which combined with the large quantity of water between the heating element and the outlet to the cooling plate, gives the result that these surface temperatures do not measurably change.

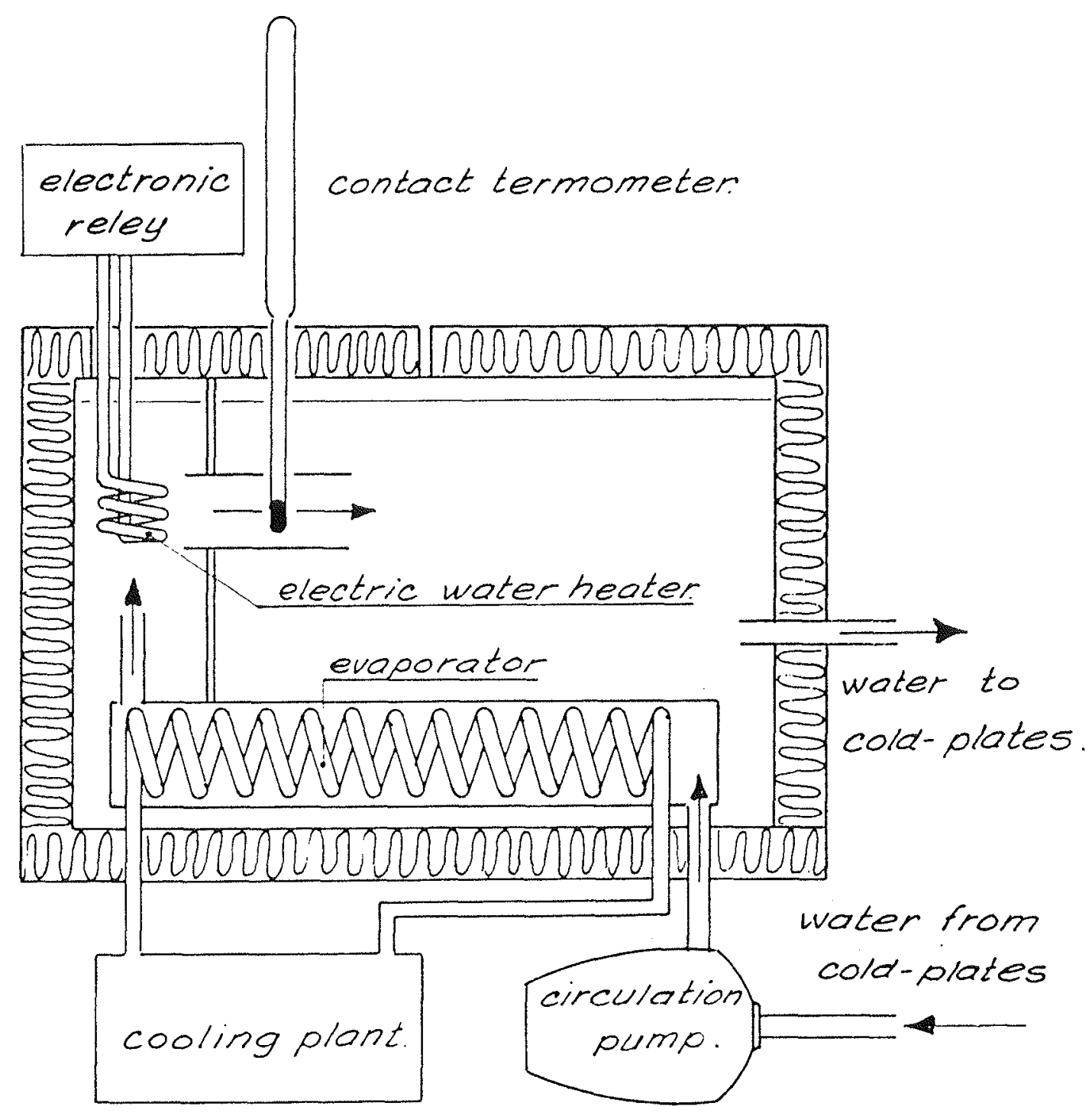

Fig. 2 - Principle sketch of cooling equipment. 
With the intention of creating vapor transport through the specimen, both the cold plate and the hot plate are equipped with a row of sponge rubber lists; it can be seen as a cross section in figure 3 . Conditioned air flows continuously through these channels.

On the cold side this ventilation does not present particular problems. The air is guided through a chamber to a series of holes in the side of the cold plate, from which it passes through the channels and is sucked up on the other side for re-conditioning (fig. 4).

On the other hand it is important that on the hot side conditioned air neither conveys nor removes heat from the test piece. This is achieved by measuring the temperature of air immediately before it flows into the channel and again immediately after it is sucked out, and next, to make sure, by help of a little heating element, that these two temperatures are identical. Air is drawn by two double-working piston pumps which work with a constant speed to provide a constant heat leakage resistance between the hot plate and the test piece. The air is conditioned by being guided through closed containers with saturated saline solution. By weighing these containers before and after measurement, it is possible partly to determine the material diffusion figure during the thermal conditions concerned, and partly to get control over the ventilation system's tightness, as the weight loss from the hot side must be the same as the weight increase on the cold side.

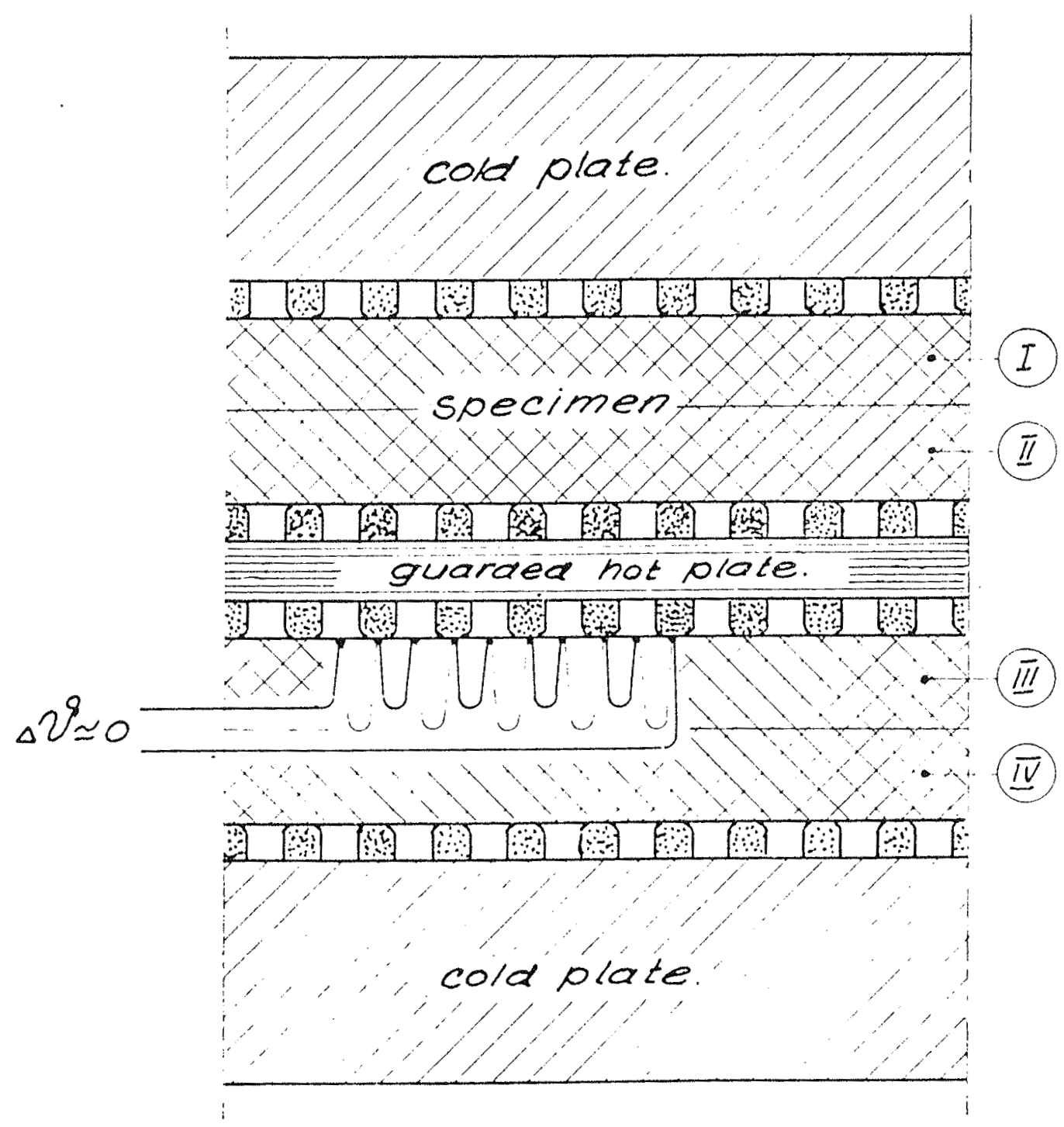

Fig. 3 - Cross section showing the location of specimens. 
Until now, the following saline solutions have been used:

$$
\begin{array}{ll}
\mathrm{MgCl}_{2} & =33 \% \mathrm{RF} \\
\mathrm{Na}_{2} \mathrm{Cr}_{2} \mathrm{O}_{1} & =52 \% \mathrm{RF} \\
\mathrm{NaCl} & =75 \% \mathrm{RF} \\
\mathrm{KNO}_{3} & =90 \% \mathrm{RF}
\end{array}
$$

\section{MEASURING EQUIPMENT}

The power which supplies the hot plate comes from a stabilised direct current distributor, which is itself supplied by a mains voltage stabiliser, and which also conveys current to the motor that drives the air pumps.

Supplied power is determined by measuring current and voltage by the hot plate terminals with a Hartmann and Brown measuring instrument, class 0.2.

The various temperature differences are measured with copper-constantan thermal elements, and are registered on a Philips 12 channel recorder.

The difference in temperature between the test piece hot and cold side is determined by five thermal elements in series, and glued to the test piece so that the wires go at right angles to the channels. This direction is chosen so that it is possible to even out differences in temperature which are a result of the heat resistance being different above sponge rubber and above air channel. The water content of conditioned air is determined by an Aqmel dewpoint meter, of the H.C.P.P type. This instrument measures the dewpoint directly, so that it can be established at which temperature the air in question causes dew formation on a mirror. This method has many advan.

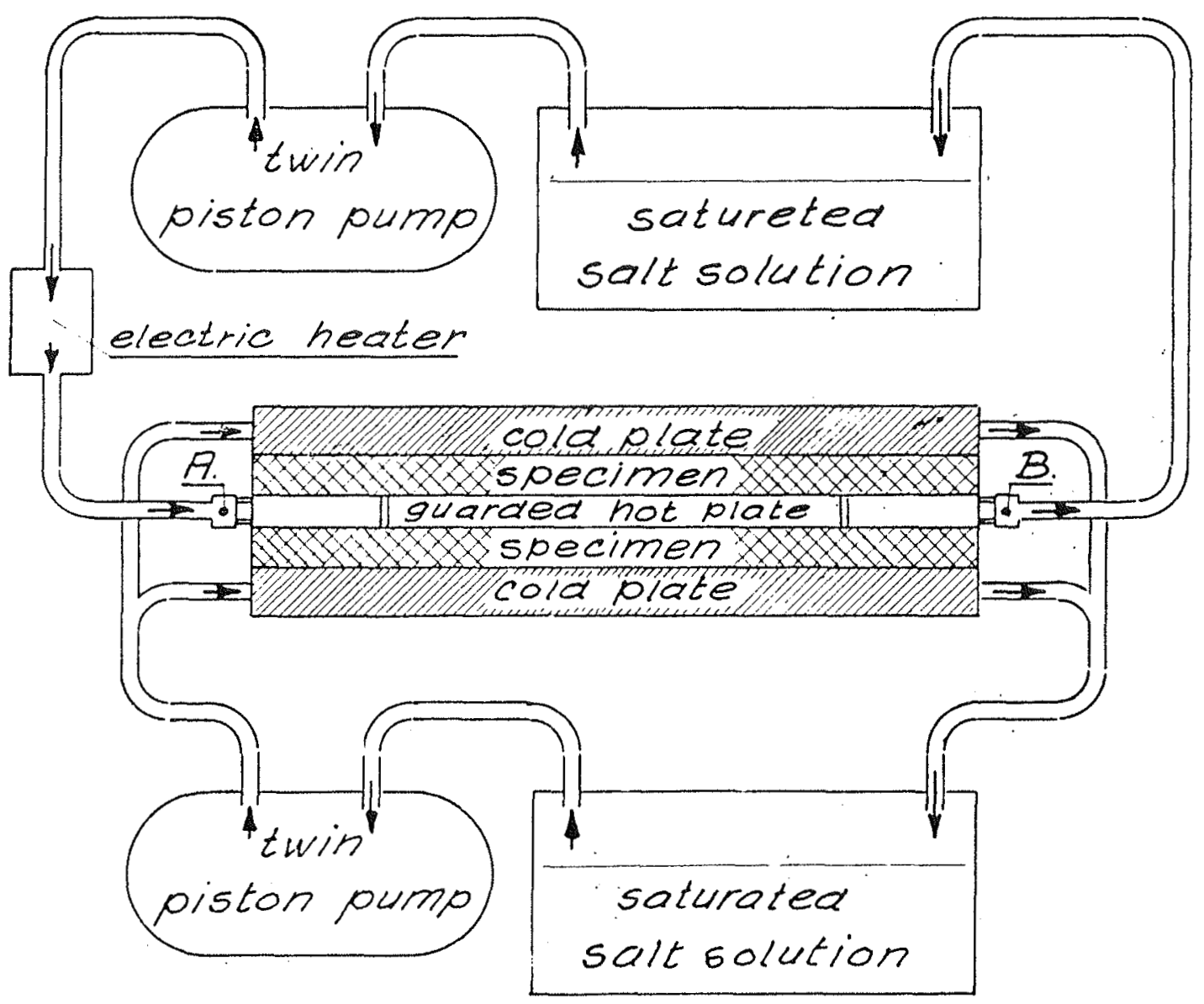

Fig. 4 - Principle sketch of air conditioning equipment. 
tages for this purpose. First, only a very little volume of air is used to determine the dew point, secondly the measurement makes no appreciable change of the air condition, and thirdly the apparatus has a very good reproducibility.

It is clear that the given design of heating and cooling plates presents the risk of hot current in the specimens not being one-dimensional because the resistance varies from rubber list to air channel.

To be able to examine this case more closely, ten thermal elements in a series $5 \mathrm{~mm}$ apart, were attached so that all the "cold" joints met with a rubber list, and all the "hot" joints met with an air gap (see fig. 3). Measuring on this thermopile shows that the test piece surface temperature is, practically speaking, the same for rubber lists as for air gaps.

It was also expected that the thermal conductivity for a $5 \mathrm{~mm}$ wide air gap according to J.S. Cammerer is $0.038 \mathrm{kcal} / \mathrm{h} . \mathrm{m}$. ${ }^{\circ} \mathrm{C}$, while the rubber list thermal conductivity is stated to be $0.040 \mathrm{kcal} / \mathrm{h} . \mathrm{m} .{ }^{\circ} \mathrm{C}$.

Heat transport is carried out one-dimensionally through the whole test element,
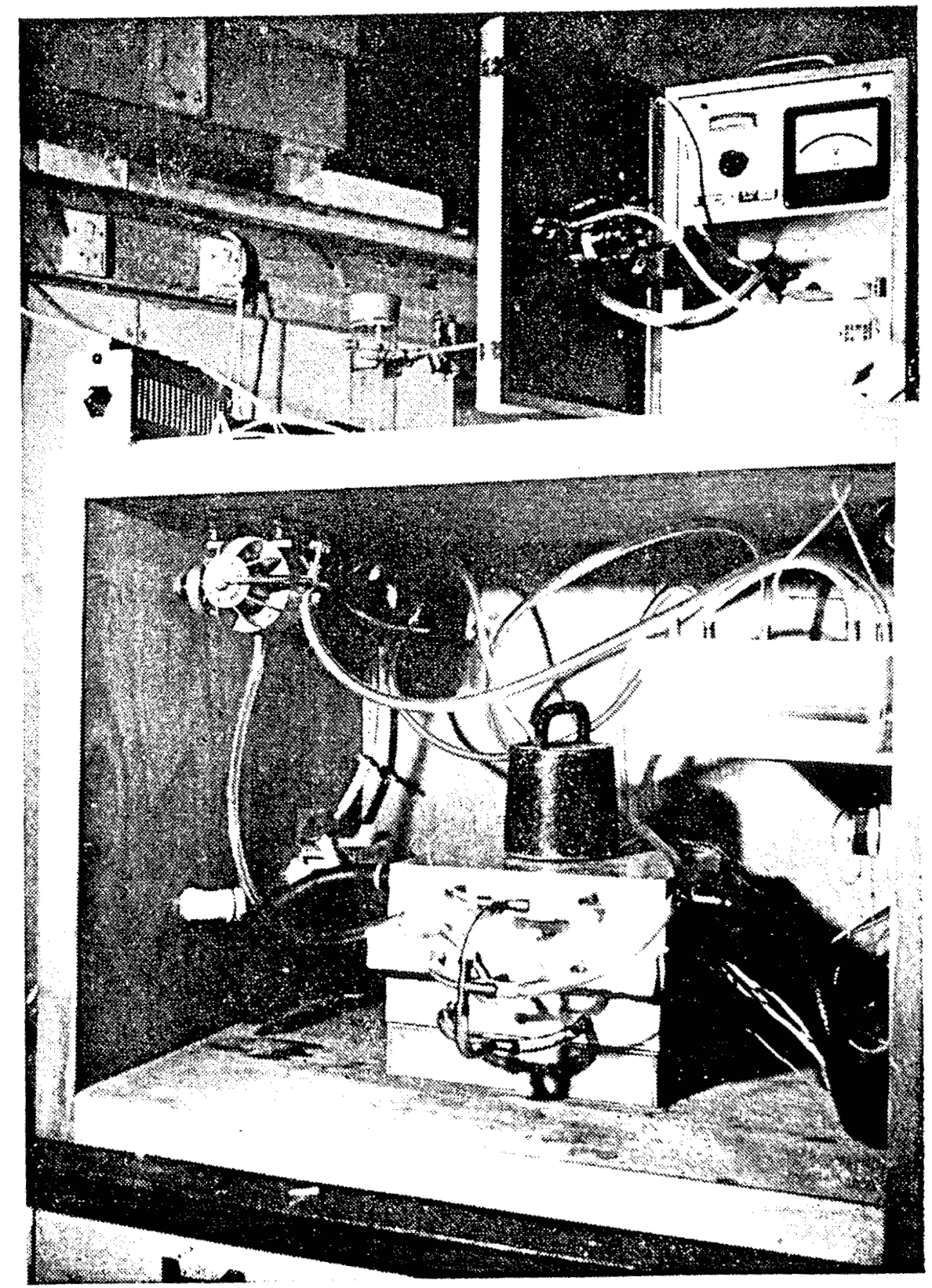

Fig. 5-General view of modified guarded hot plate apparatus. At top right is seen the dewpoint meter. 


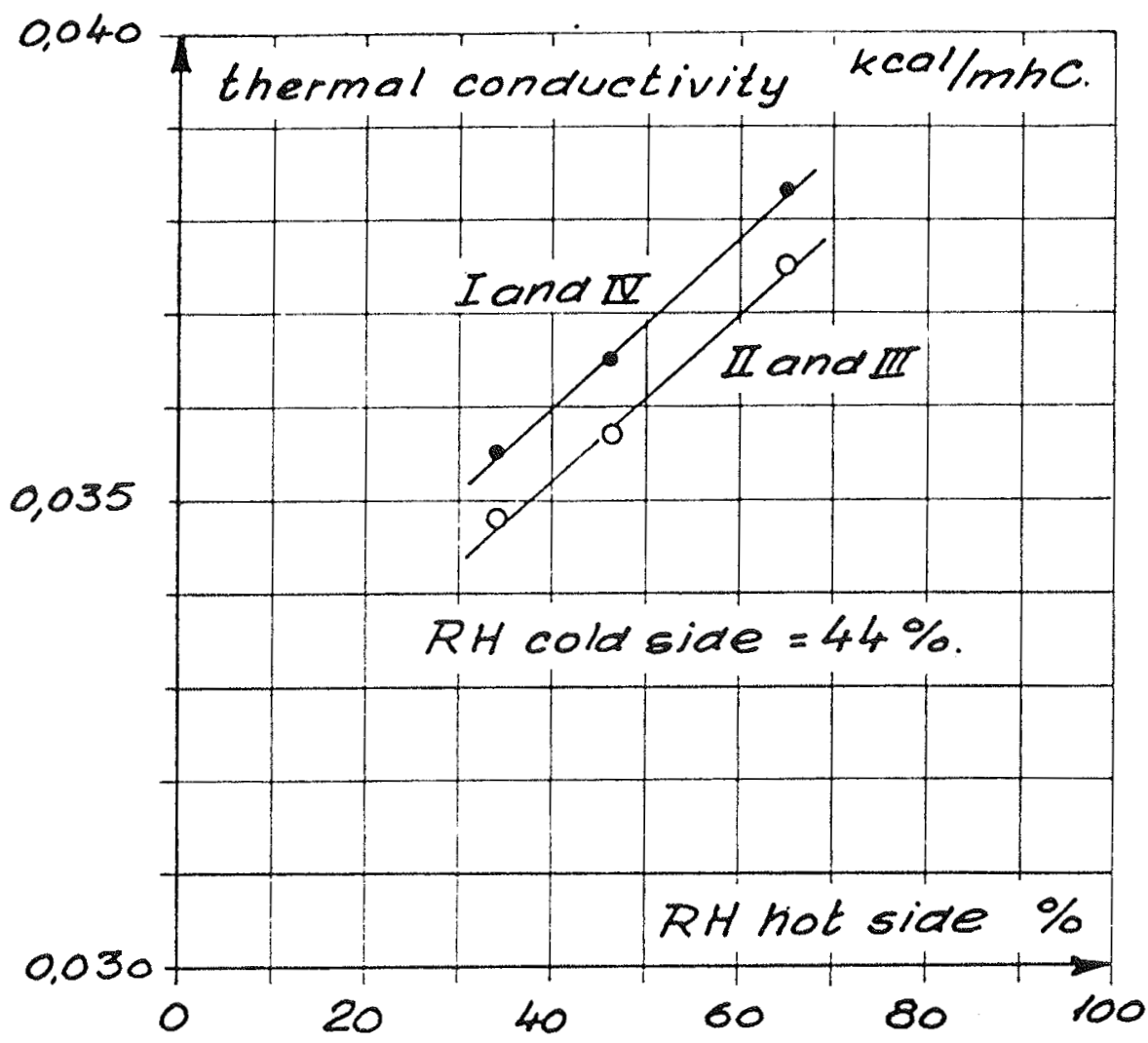

Fig. 6- The thermal conductivity of soft fibre board in dependence on the relative humidity of the hot side.

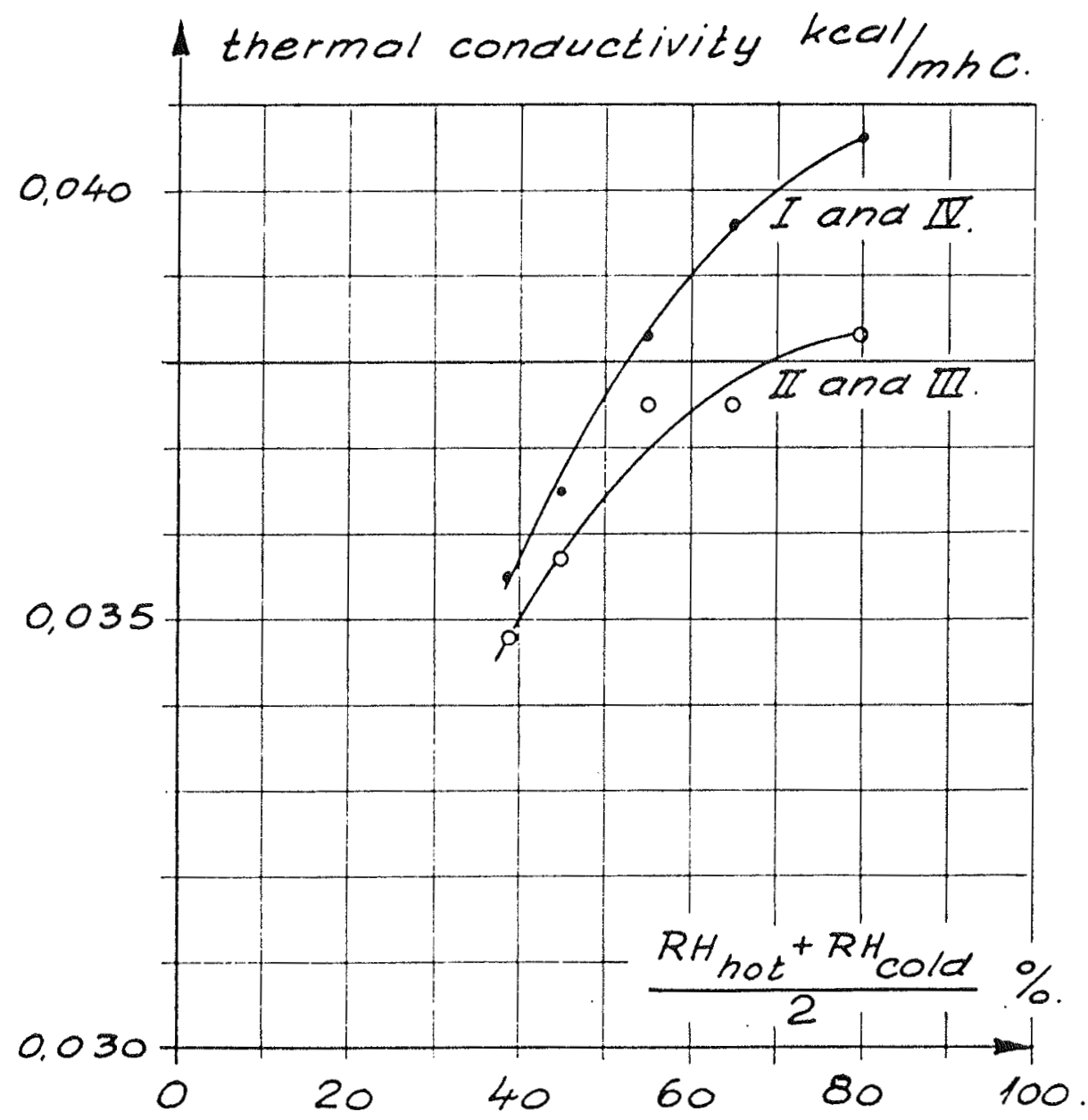

Fig. 7 - The thermal conductivity of soft fibre board in dependence on average relative humidity at cold and hot side. 
whereas the transport of vapor is carried out two-dimensionally near the surface, because water vapor can only diffuse in and out of the test pieces where the specimens are limited by the air gaps.

During the measurement, the edges of test pieces are covered with vapor-tight tape, so that the water vapor and the outside space cannot be exchanged. The whole installation is as shown in figure 5 put in an insulated box whose interior is kept at the test piece average temperature by suitable exposure of the cold plates.

\section{MEASURING RESUlTS}

Until now measurements have only been taken on 4 pieces of $\frac{1}{2}$ in. soft fibre board with a dry weight of $240 \mathrm{~kg} / \mathrm{m}^{3}$.

Table 1

THE THERMAL CONDUCTIVITY OF SOFT FIBRE BOARD IN DEPENDENCE ON THE RELATIVE HUMIDITY AT THE COLD AND THE HOT SIDE

\begin{tabular}{|c|c|c|c|c|c|c|c|}
\hline \multicolumn{2}{|c|}{$\begin{array}{l}\text { Relative air } \\
\text { humidity \% }\end{array}$} & \multicolumn{2}{|c|}{ Temperature ${ }^{\circ} \mathrm{C}$} & \multicolumn{2}{|c|}{$\begin{array}{l}\text { Vapor content } \\
\text { weight percent }\end{array}$} & \multicolumn{2}{|c|}{$\begin{array}{c}\text { Thermal conductivity } \\
\mathrm{kcal} / \mathrm{h} . \mathrm{m} .{ }^{\circ} \mathrm{C}\end{array}$} \\
\hline cold side & hot side & cold side & hot side & $I$ and $I V$ & $I I$ and III & $I$ and $I V$ & II and III \\
\hline 44 & 34 & +18.3 & 23.6 & 5.7 & 5.3 & 0.0355 & 0.0348 \\
\hline 44 & 46 & +18.3 & 23.6 & & & 0.0365 & 0.0357 \\
\hline 44 & 65 & +18.8 & 23.8 & & & 0.0383 & 0.0375 \\
\hline 57 & 74 & +18.8 & 23.7 & & & 0.0396 & 0.0375 \\
\hline 81 & 80 & +18.8 & 23.7 & 16.0 & 11.4 & 0.0406 & 0.0383 \\
\hline
\end{tabular}

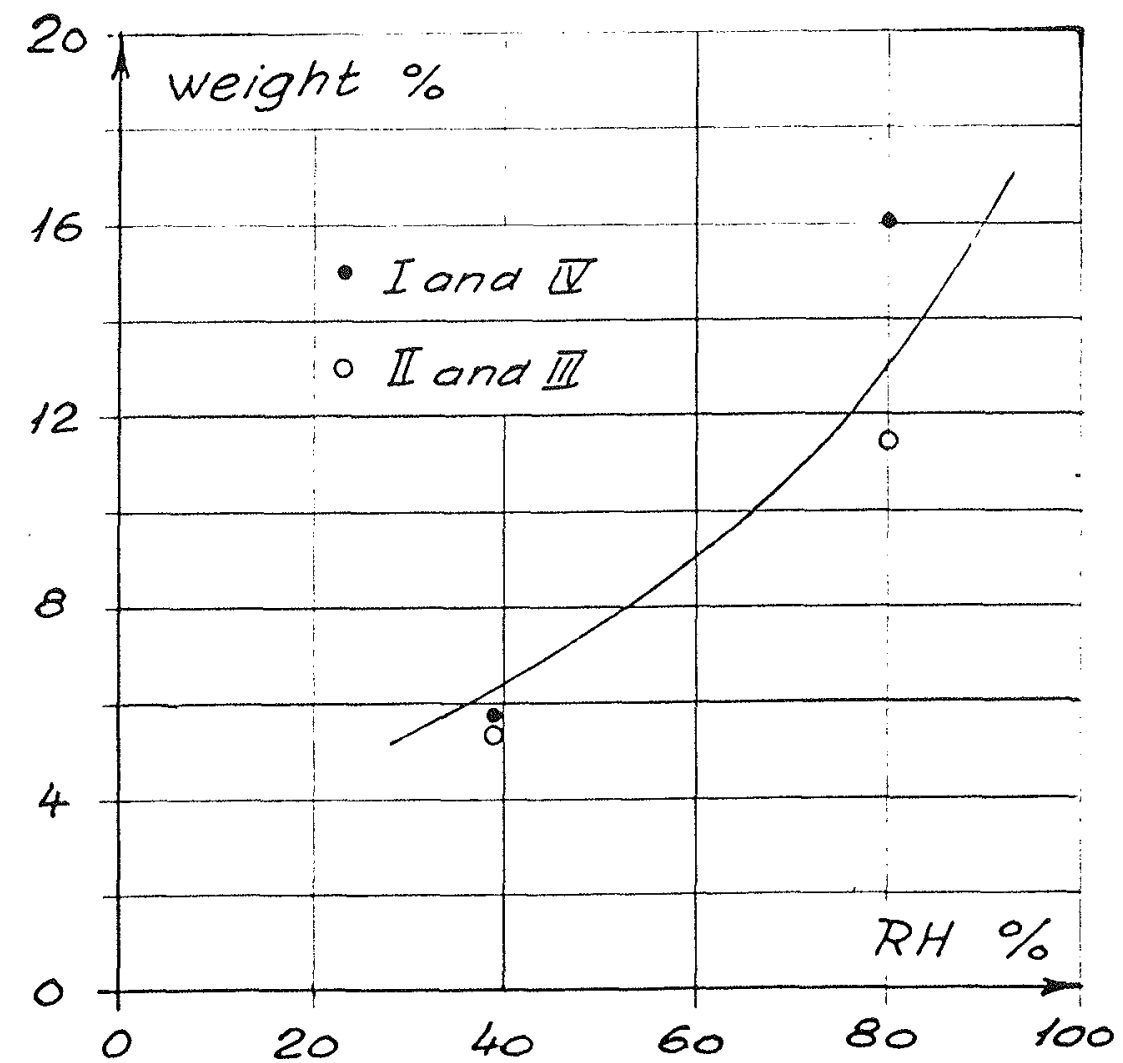

Fig. 8 - Vapor content in soft fibre board in dependence on relative humidity, compared with a sorption curve specified by P. Lund-Hansen, 1967. 
The result of these measurements is shown in table 1 and figures 6 and 7 . The position of the boards is shown in figure 3.

So as not to change the conditions of the experiment en route, the boards were only weighed immediately before the thermal measurement begun and again immediately after they were finished. Afterwards, the boards were dried at a temperature of $+55^{\circ} \mathrm{C}$ until they reached a constant weight. From this weight, the vapor content from the first and last measurements was calculated. The result is shown in figure 8 together with a sorption curve for soft fibre board as specified by P. Lund-Hansen in "Moisture Transfer in Building Materials", 1967.

\section{DISCUSSION}

B.H. VOS (The Netherlands) - In the first place I want to state that as far as I know, this is the first apparatus that can teach us more about the variation of thermal conductivity under realistic boundary conditions. We have to bear in mind that thermal conductivity is not at all a constant property:

$$
\lambda=\lambda(\bar{T}, \operatorname{grad} . T, \Psi, \operatorname{grad} . \bar{\Psi}, \alpha)
$$

thickness $(\alpha)$. This parameter enters into the function as a consequence of radiation, depending strongly upon temperature.

temperature (T). The influence of this parameter is well known.

moisture content $(\psi)$. These vapour transfer in the pores - evaporation and condensa-

tion - plays an important part.

moisture and temp. gradient (grad. $\psi$, grad. T)

Both gradients together determine flow of vapour and water in liquid form in the material.

Of course one can give a definition of thermal conductivity by:

$$
\begin{aligned}
& \lambda=\lim \lambda(\Psi, T, \operatorname{grad} . \Psi, \operatorname{grad} . T, \alpha)
\end{aligned}
$$

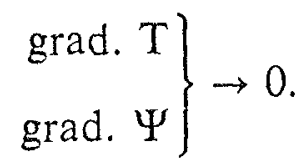

However a property is found that is only of academical value. We cannot work with it. I think the apparatus as it has been developed by the author can provide us with more information about what really happens than any other way of approach. Especially thermal conductivity of structures that are closed at one side and open at the other side can be compared with two-sided open structures. Unfortunately the author whill have to restrict himself to the hygroscopic moisture range. In practice also the higher region are of great interest, primarily around critical water content. Therefore I hope that also measuring devices can be suitably developed for measurement in this region.

D. FOURNIER (France) - 1. Je pense qu'il faut tenir compte dans les problèmes relatifs à la mesure de la conductivité thermique et en particulier dans les mesures comparatives telles que celles organisées par l'I.I.F., non seulement des paramètres déjà nombreux cités par $M$. Vos et qui caractérisent l'influence des conditions de mesure sur la conductivité thermique d'un échantillon donné, mais aussi de paramètres caractéristiques du matériau lorsque plusieurs échantillons sont en cause.

En effet un isolant industriel n'est pas un corps pur parfaitement homogène, loin de là. Pour un isolant fibreux par exemple il faut ajouter au paramètre « épais- 